\title{
NEW VIEWS OF FREEDMAN LABOR AND EUROPEAN PUBLISHING
}

At the 1976 meeting (November 10-13) of the Southern Historical Association in Atlanta, several scholars delivered papers related to working class history. Two addressed themselves directly to central interests of American labor historians, while others illuminated the social fabric of the European world of work.

One session focused on the efforts of freed slaves to adjust to the postbellum labor system. Armistead Robinson (University of California, Los Angeles) argued that the ability of freedmen to improve their economic conditions was hindered by their experiences in slavery and by the demands of the capitalistic economic system. ${ }^{1}$ For example, ex-slaves often refused to move to lucrative jobs because of attachment to families and kin on the plantation. Also, because capitalists wanted a salaried agrarian labor force. Union soldiers ensured that blacks would not acquire property. Armistead's contentions about the impact of capitalism on the freedman were not always convincing. He overlooked completely the efforts by Northerners to provide the ex-slaves with land in the Port Royal area-where, Willie Lee Rose contends, the Northern administrators failed to distribute property for mostly political, not economic reasons. ${ }^{2}$

Paired with Robinson's paper was a presentation by Ronald L.F. Davis (California State University, Northridge). ${ }^{3}$ Unlike Robinson, Davis was interested in the achievements of the freedmen, and he suggested that, contrary to conventional wisdom, sharecropping was more efficient than slave labor. A sophisticated statistical study of land and labor around Natchez. Mississippi, in 1859 and 1879 supported his argument. By comparing agrarian production at these two times, he found sharecropping economically superior to slavery. Although the research showed considerable care, there are methodological reasons to doubt the findings. Even twentieth-century farmers would insist that no single year is a reliable indicator of normal production. Furthermore, Davis based his conclusions largely on land in a particularly fertile area. Probably in a free economy the most industrious would have monopolized this fertile bottom land. Would sharecroppers relegated to poor land have performed better than slaves on the same property? The papers together cast an interesting light on the freedmen, struggling with their backgrounds and prospects. to eke out a living and enjoy their freedom.

The history of publishing should also be important to labor historians, since many have relied on books and magazines to ascertain the views of the working classes. Because the letters of laborers were not generally saved, pulp literature provides some hint of the intellectual milieu. But to use journals and paperbacks reliably, the interaction among authors, editors, and the public must be examined. When these relationships are clear, the historian may evaluate more accurately these sources and may exploit them to show how attitudes were shaped or were reinforced. Through an understanding of publishers' motives, an enormous data bank may be opened.

Two papers delivered at the Southern focused on German publishers who, in the late nineteenth century, enjoyed new possibilities created by higher literacy rates, improved technology, and stronger copyright laws. By investigating the activities of two publishing houses. Gary D. Stark (University of Texas at Arlington) showed how publishers increasingly adopted the attitudes and responsibilities of the Renaissance patron.' For example, publishers often used their money and influence to provide financial support for retired authors. Stark concluded optimistically for the writers; he suggested that those publishers who sponsored authors actually provided the basis for future financial and literary freedom. 
Ronald A. Fullerton (Madison Area Technical College) was also concerned with publishers, but of a very different sort. ${ }^{6}$ The publishers analyzed in his paper produced from 1870 to 1914 sensational novels, serials, newspapers, and magazines for children and poorly educated adults. As one of the commentators at this session put it, "When they thought about making their mark, they spelled it with a capital M."' They could hardly have cared less about their authors. Nevertheless, these publishers, according to Fullerton, "inaugurated the modern era of popular culture in Germany, "s for what they printed set the standard for such publications in the twentieth century.

Taken together these two interesting papers argued that the development of a mass market gave publishers a more significant role than they had occupied before. Prestigious publishers exercised the authority of the patron; popular houses earned great sums and dictated public taste. But was this a new role? Both commentators for this session alluded to the paucity of the literature on the press.9 Perhaps further investigation into German publishing will reveal what historians have discovered about France. In the sixteenth and seventeenth centuries there were publishers who acted very much like those described by Fullerton. ${ }^{10}$ Other historians have written about eighteenth century publishers who subsidized and controlled the careers of budding young authors. ${ }^{11}$ Furthermore, even the Old Regime developed a system of support for superannuated writers. ${ }^{12}$ Possibly continued research will indicate that the publishers of late nineteenth-century Germany operated within a well-established tradition.

All of these papers, with the exception of Robinson's emphasized change-for freedmen and for publishers-in the late nineteenth century; on the other hand, most of my comments and those of the panelists focused on the continuity of experience. This tension is a common one. Authors are impressed with the diversity and the richness of their subjects and find in them something new; critics seek to understand and to this end search for precedents and related work. It may be useful for both critics and authors to consider the pervasiveness of this pattern.

Jack R. Censer

College of Charleston

1. Armistead Robinson, "The Bottom Rail on Top, Dis Time' Sure: Freedmen and the Adjustment to Free Labor in the Civil War."

2. Willie Lee Rose. Rehearsal for Reconstruction: The Port Royal Experiment (Indianapolis: Bobbs-Merrill. 1964).

3. Ronald L. F. Davis, "The Relative Efficiency of Slave and Sharecrop Labor: A Comparative Analysis." Louis S. Gerteis, of the University of Missouri. St. Louis, was the commentator for this session on freedmen, and his remarks were judicious and incisive.

4. For an example, see Louis Galambos. The Public Image of Big Business in America. 1880-1940: A Quantitative Study in Social Change (Baltimore: Johns Hopkins, 1975).

5. Gary D. Stark, "Publishers and Cultural Patronage in Germany. 1890-1933."

6. Ronald A. Fullerton. "German Publishers and the Masses in Wilhelmian Germany."

7. Andrew Lees, Rutgers University. Camden.

8. Fullerton. p. 13.

9. Lees and Charles E. McClelland. University of New Mexico.

10. See Robert Mandrou. De la Culture populaire aux $17^{\mathrm{e}}$ et $18^{\mathrm{e}}$ siècles. La Bibliothèque bleue de Troyes (Paris, 1964).

11. See Frances Acomb. Mallet du Pan 1749-1800: A Career in Political Journalism (Durham: Duke University Press. 1973) and Raymond Birn. Pierre Rousseau and the Philosophes of Bouillon (Geneva: Studies on Voltaire and the 18th century. Vol. XXIX. 1964).

12. Pensions were usually available for authors who had worked for one publisher for a long time. Journals often used indemnities that were awarded in copyright disputes to fund these stipends. 